EPiC Series in Education Science
Volume 1, 2017, Pages 139-146
$\begin{aligned} & \text { AUBEA 2017: Australasian Universities Build- } \\ & \text { ing Education Association Conference 2017 }\end{aligned}$

\title{
Profitability of Large Commercial Construction Companies in Australia
}

\author{
Toong Khuan Chan ${ }^{1}$ and Igor Martek ${ }^{2}$ \\ ${ }^{1}$ University of Melbourne \\ ${ }^{2}$ Deakin University \\ tchan@unimelb.edu.au, igor.martek@deakin.edu.au
}

\begin{abstract}
Increased competitiveness in the Australian building and construction industry has led to reduced profits for builders particularly for tier 1 builders offering essentially undifferentiated offerings. An analysis of the profitability of a sample of large commercial builders based in Victoria have confirmed that net profit margins for these companies are 2 and 3 percentage points of total revenues - wafer thin. The aims of this paper are to characterise the profitability of these commercial builders by examining a range of profitability measures, and to investigate this loss of value across the construction supply chain. The findings indicate that the average net profit margin has nearly halved from $3.2 \%$ in 2006 to $1.7 \%$ in 2015 . Companies with large revenues, those exceeding $\$ 500$ million annually, exhibit a generally lower profitability than smaller companies. Despite this lower profitability, return for shareholders remains reasonable with an average return on equity of $20 \%$ reflecting a shift to higher leverage, lower risk, asset light business model. Like all businesses, construction companies must demonstrate their financial viability by turning a profit and providing a convincing riskadjusted return to their investors. Empirical evidence suggests that companies reporting low profitability are at increased risk of insolvency. Failure to acknowledge this may lead to serious financial implications for the industry and the economy.
\end{abstract}

\section{Introduction}

The recent IBISWorld Industry Report for Commercial and Industrial Building Construction in Australia (Kelly, 2016), presents an optimistic outlook for the Australian construction sector. It states: "The industry's solid performance over the past five years has supported the gradual widening of profit margins." (p. 5). The years 2010-11 saw a significant cyclical downturn in the economy, which impacted the construction sector. The intervening period of economic rebound provided opportunities for recovery as construction firms met latent demand for warehousing, transport infrastructure, 
commercial space, hotels, and industrial expansion. Annualized revenue growth over the last five years is estimated at $3.5 \%$, and the trend is projected to continue.

There is, however, cause for scepticism. The construction industry is mature, and as such cannot expect sustained growth beyond that of the overall economy. Australia's annualized GDP growth rate, through to 2021 , is projected at only $2.6 \%$. Moreover, since the industry is predominantly populated by small firms, with only $3 \%$ employing more than 20 people, entry barriers are low and competitive intensity is high. Compounding this dynamic, the construction industry has seen year on year increases in the number of active participants. These factors, combined with limited opportunities for off-shore expansion, modest technological developments in efficiency, and increasing costs, can be expected to put downward pressure on profits and ultimately to thin out the industry into a smaller number of competitors.

Currently, the yield on Australian Government ten-year bonds is 2.5\%, with bank deposits paying $2.4 \%$. Given the substantial risks associated with construction, should profit rates approach these levels the incentive to remain in the market would be marginal. While exiting the market is easier for small operators, exit costs for large firms with substantial capital assets are high. A ubiquitous strategy employed by firms subject to high market exit costs in a declining profit environment, is to endure losses for as long as possible, while waiting for the industry to return to profitability. Profitability returns as players are culled through bankruptcy or acquisition, and competitor concentration is reduced.

While IBIS reports revenue growth for the largest construction companies at between 7 to $10 \%$, Deloitte claims profit margins can be as low 0.3\%. (Deloitte, 2016) The labour costs for Victorian firms are the highest, and it is the larger Victorian construction firms that may be experiencing the greatest erosion of profits. A sustained industry-wide reduction in risk-adjusted profit levels would portend a looming rationalization of the industry. This study sets out to quantify the profitability of large Victorian based construction companies, and describe trends in profitability over time.

\section{Literature Review}

Previous research on company profitability where profitability and other financial ratios were utilised for managerial analysis can be found in a review by Horrigan (1968). Beaver (1966), and later Altman (1968), suggested statistical models that were based on financial ratios to predict the risk of company failures. One of the earliest studies on the construction sector was carried out by Fadel (1977) for UK enterprises indicating that companies with larger revenues were more profitable. In a similar vein, Akintoye and Skitmore (1991) found that the profitability of UK general contractors was positively correlated with company size.

The shortcomings of profitability or ratio analysis include the absence of an explicit theoretical framework. Nevertheless, ratio analysis remains a simple and quick method that enables financial performance to be compared between firms and over time.

\section{Methodology}

The approach adopted for this empirical research into the profitability of commercial construction companies is to use annual financial statements. The source data was obtained from the Company 360 database, a business tool provided by Dun \& Bradstreet. This service collates the financial statements companies submit to the Australian Securities and Investments Commission (ASIC). Only large proprietary companies, defined as one that satisfies at least two of the following criteria: revenues exceeding \$25 million, gross assets exceeding \$12.5 million, or employs 50 or more people; need to 
prepare and lodge financial reports. Smaller proprietary companies do not usually lodge financial statements unless directed to do so by the AISC, limiting the amount of financial data available for this analysis.

This data source provides access to a large number profit \& loss accounts and balance sheets for companies with their corresponding standard industrial classification (SIC) code. Commercial construction companies are registered under an SIC of 1542 - General Contractors - Non-residential Buildings, Other Than Industrial Buildings and Warehouses. The SIC code is a four-digit numerical code assigned by the US government to business establishments to identify the primary business of the establishment, and is adopted by Dun \& Bradstreet, a US company. Some companies report both a primary and several subsidiary SIC codes, and a search for SIC $=1542$ revealed that a total of 1,155 companies in Australia. Twenty four percent of these companies or 278 are registered in the state of Victoria, our primary location for this study. Only 166 companies reported 1542 as a primary SIC and 27 of these presented sufficient financial data for this analysis. These 27 companies are listed in Table 1.

\begin{tabular}{lllc}
\hline No & DUNS & Company Name & Employees \\
\hline 1 & 743145369 & ACCIONA INFRASTRUCTURE AUSTRALIA PTY LTD & 237 \\
2 & 740825070 & ADCO CONSTRUCTIONS (VIC) PTY LIMITED & 125 \\
3 & 741085880 & APM GROUP (AUST) PTY LTD & 53 \\
4 & 750256760 & BAY BUILDING SERVICES PTY. LTD. & 140 \\
5 & 753284660 & BECON CONSTRUCTIONS PTY. LTD. & 153 \\
6 & 741234116 & BUILT VIC PTY LTD & 43 \\
7 & 744119350 & CAELLI CONSTRUCTIONS (VIC) PTY LTD & 637 \\
8 & 756701546 & CAMILLO CONCRETE STRUCTURES PTY LTD & 66 \\
9 & 751826801 & CMW DESIGN \& CONSTRUCT (VIC) PTY. LTD. & 25 \\
10 & 741329119 & CONTRACT CONTROL SERVICES PTY LTD & 42 \\
11 & 741696306 & CREMA CONSTRUCTIONS PTY LTD & 200 \\
12 & 753452770 & E.J. LYONS \& SONS PROPRIETARY LIMITED & 38 \\
13 & 757403204 & FDC CONSTRUCTION \& FITOUT (VIC) PTY LIMITED & 53 \\
14 & 750745200 & FORM 700 HOLDINGS PTY LTD & 892 \\
15 & 754199677 & GEORGE RYDELL CONSTRUCTIONS PTY. LTD. & 25 \\
16 & 745047485 & GROCON CONSTRUCTORS (VICTORIA) PTY LTD & 50 \\
17 & 753043637 & GROCON PTY. LIMITED & 290 \\
18 & 753662618 & KANE CONSTRUCTIONS PTY LTD & 270 \\
19 & 754508836 & LLOYD GROUP PTY LTD & 15 \\
20 & 752223581 & MABEN GROUP PTY. LTD. & 40 \\
21 & 89071153 & MELBOURNE INDUSTRIES PTY. LTD. & 20 \\
22 & 753349588 & MERKON CONSTRUCTIONS PTY. LTD. & 59 \\
23 & 744175142 & MONACO HICKEY PTY. LTD. & 16 \\
24 & 752067871 & MULTIPLEX CONSTRUCTIONS PTY LTD & 400 \\
25 & 752865857 & PELLICANO BUILDERS PTY. LTD. & 110 \\
26 & 740985106 & PROBUILD CONSTRUCTIONS (AUST) PTY LTD & 748 \\
27 & 746938810 & SJ HIGGINS CONSTRUCTIONS PTY LTD & 12 \\
\hline
\end{tabular}

Table 1: List of construction companies investigated, along with their corresponding DUNS number and number of employees 


\section{Results}

The revenues of the sample companies range from $\$ 14$ million to $\$ 2.5$ billion per year while the total assets range from $\$ 6.5$ million to $\$ 1.1$ billion. The profitability of these companies is assessed by examining 5 profitability ratios from 2006 to 2015 . These ratios are (i) net profit margin, (ii) EBITDA margin, (iii) Return on Equity (ROE), (iv) Return on Total Assets (ROA) and (v) Return on Capital Employed (ROCE). These profitability ratios are presented in Table 2 as statistical means $(\mu)$ of these ratios, standard deviations $(\sigma)$, and finally as an aggregate mean $\left(\mu_{-} 2\right)$ (calculated as a ratio of the sum of profits of the sample companies divided by the sum of revenues).

\begin{tabular}{lrrrrrrrrrr}
\hline $\begin{array}{l}\text { Financial } \\
\text { ratios }\end{array}$ & 2006 & 2007 & 2008 & 2009 & 2010 & 2011 & 2012 & 2013 & 2014 & 2015 \\
\hline NPM $(\mu)$ & 4.0 & 2.9 & 3.9 & 3.1 & 1.5 & 2.2 & 1.4 & 1.3 & 1.2 & 1.4 \\
NPM $(\sigma)$ & 2.3 & 2.6 & 2.8 & 2.6 & 3.1 & 3.7 & 3.2 & 2.0 & 2.1 & 2.0 \\
NPM $\left(\mu \_2\right)$ & 3.2 & 2.8 & 3.6 & 3.3 & 2.5 & 1.2 & 2.8 & 2.1 & 1.6 & 1.6 \\
EBITDA $(\mu)$ & 5.4 & 4.1 & 5.4 & 4.3 & 1.9 & 2.6 & 1.7 & 1.3 & 1.8 & 2.1 \\
EBITDA $(\sigma)$ & 3.8 & 3.5 & 3.7 & 3.7 & 4.5 & 5.2 & 5.0 & 3.0 & 3.1 & 2.8 \\
EBITDA $\left(\mu \_2\right)$ & 3.0 & 4.7 & 5.5 & 5.2 & 4.0 & 1.7 & 4.4 & 3.9 & 2.6 & 2.9 \\
ROE $(\mu)$ & 56.5 & 1.9 & 90.8 & 77.7 & 21.0 & 37.2 & 28.6 & 30.9 & 23.2 & 24.5 \\
ROE $(\sigma)$ & 45.8 & 129 & 76.6 & 141 & 45.4 & 51.9 & 24.5 & 34.9 & 53.1 & 39.5 \\
ROE $\left(\mu \_2\right)$ & 46.4 & 35.6 & 43.7 & 27.8 & 19.0 & 9.0 & 26.1 & 27.4 & 19.4 & 21.0 \\
ROA $(\mu)$ & 12.0 & 9.0 & 17.3 & 9.3 & 5.4 & 7.6 & 5.4 & 4.3 & 4.1 & 3.9 \\
ROA $(\sigma)$ & 8.5 & 12.0 & 11.8 & 10.4 & 9.6 & 6.5 & 5.1 & 6.2 & 6.2 & 5.7 \\
ROA $\left(\mu \_2\right)$ & 7.1 & 4.9 & 7.4 & 6.3 & 5.0 & 3.1 & 7.4 & 6.4 & 4.8 & 5.0 \\
ROCE $(\mu)$ & 55.8 & 34.3 & 93.3 & 68.5 & 7.8 & 30.3 & 48.5 & 38.6 & 29.4 & 22.7 \\
ROCE $(\sigma)$ & 54.7 & 86.7 & 61.4 & 77.2 & 74.6 & 56.4 & 61.7 & 41.1 & 42.3 & 27.6 \\
ROCE $\left(\mu \_2\right)$ & 36.6 & 52.6 & 58.6 & 37.9 & 25.8 & 10.3 & 31.9 & 31.6 & 23.7 & 25.8 \\
TP/TA $(\mu)$ & 37.8 & 45.0 & 43.5 & 40.1 & 41.1 & 38.2 & 41.3 & 42.6 & 41.7 & 34.8 \\
TP/TA $(\sigma)$ & 18.8 & 23.7 & 18.4 & 19.1 & 19.3 & 17.3 & 16.6 & 16.0 & 16.1 & 17.0 \\
TP/TA $\left(\mu \_2\right)$ & 26.1 & 15.8 & 21.4 & 27.2 & 2.4 & 24.3 & 32.4 & 33.9 & 31.7 & 29.0 \\
\hline
\end{tabular}

Table 2: Company financial ratios for years 2006 to 2015

The mean net profit margin fell from a high of $4.0 \%$ in 2006 to $1.4 \%$ in 2015 . The fall in profit margin in 2010 was indicative of the slowdown in the construction industry despite additional fiscal spending on infrastructure and the construction of schools in response to the global financial crisis. Profit margins have remained at this low level from 2010 until 2015. If all 27 companies are to be considered in aggregate, the highest profit margin was reported in 2008 at $3.6 \%$ but declined to a low of $1.2 \%$ in 2011, recovered the following year to $2.8 \%$. It was a low $1.6 \%$ for 2014 and 2015 indicating that profitability in the commercial construction sector remained poor. Very similar trends were observed for EBITDA - an indication of operating performance without taking into account financing, accounting or tax issues. A scatter plot of net profit margins against revenue, shown in Figure 1, indicates that companies with larger revenues exhibit net profit margins within a narrow $2 \%$ to $4 \%$ band, whereas companies reporting revenues less than $\$ 500$ million exhibited profit margins from $-6 \%$ to $10 \%$. When the same data is plotted over time as in Figure 2, all the companies were reporting net profit margins of up to $10 \%$ before 2010. From 2011 onwards, a number of companies started to report losses while the aggregate mean profit margins declined. By $2015,90 \%$ of the companies reported net profit margins of less than $2.3 \%$.

A similar analysis on the return on average equity (ROE) indicated that these returns were at $40 \%$ in 2008 and earlier, but fell to around 20\% in 2014 and 2015. This was clearly a consequence of the lower profits during those two years. The return on capital employed (ROCE), which measures the 
return over the sum of both equity and long-term borrowings, indicated a slightly higher value compared to ROE but the general trends were similar. Pre-2008 ROCE was between $40 \%$ and $60 \%$ whereas 2014-2015 aggregate was between $24 \%$ and $26 \%$.

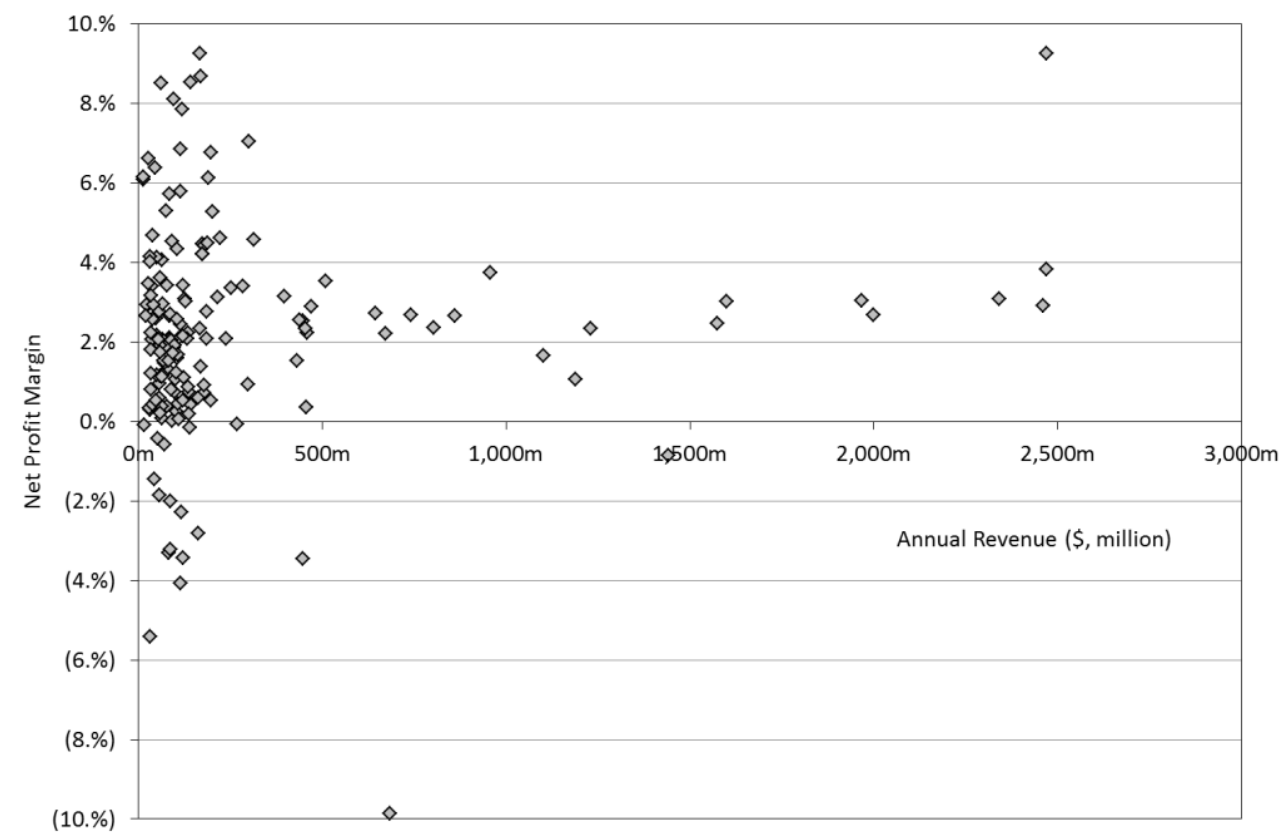

Figure 1: Net profit margin for sample of commercial construction firms

Return on total assets (ROA), which measures how effectively the construction company is utilising its assets to generate earnings, declined from a high of 7.4\% in 2008 to about 5\% in 2015 . One major characteristic of the commercial construction sector is the existence of large trade payables as part of total assets which, on the surface, serves to inflate total assets to such an extent that it dilutes ROA. But on closer examination and analysis, this trade payable may be utilised to finance construction work, allowing under-capitalised companies to take on large projects, where working capital is generated from increasingly larger operations. Other than a year of low trade payable/total asset ratio in 2007, trade credit has remained at between $21 \%$ and $27 \%$ before 2012 but increased to more than $30 \%$ in 2012 and beyond.

\section{Discussion}

Reported total revenues for the Australian commercial and industrial building construction sector for 2015-16 are \$33.5 billion, with a total profit of $\$ 1.7$ billion (Kelly, 2016). This gives a profit to revenue ratio of $5.0 \%$. Victoria represents $27 \%$ of the total Australian construction market. For the large, Victorian construction firms surveyed in this study, the profit to revenue ratio for 2015 stood at a mere $1.6 \%$. Given the industry revenue volatility of $10 \%$, this is a poor and, more notably, unsustainable performance outcome. 


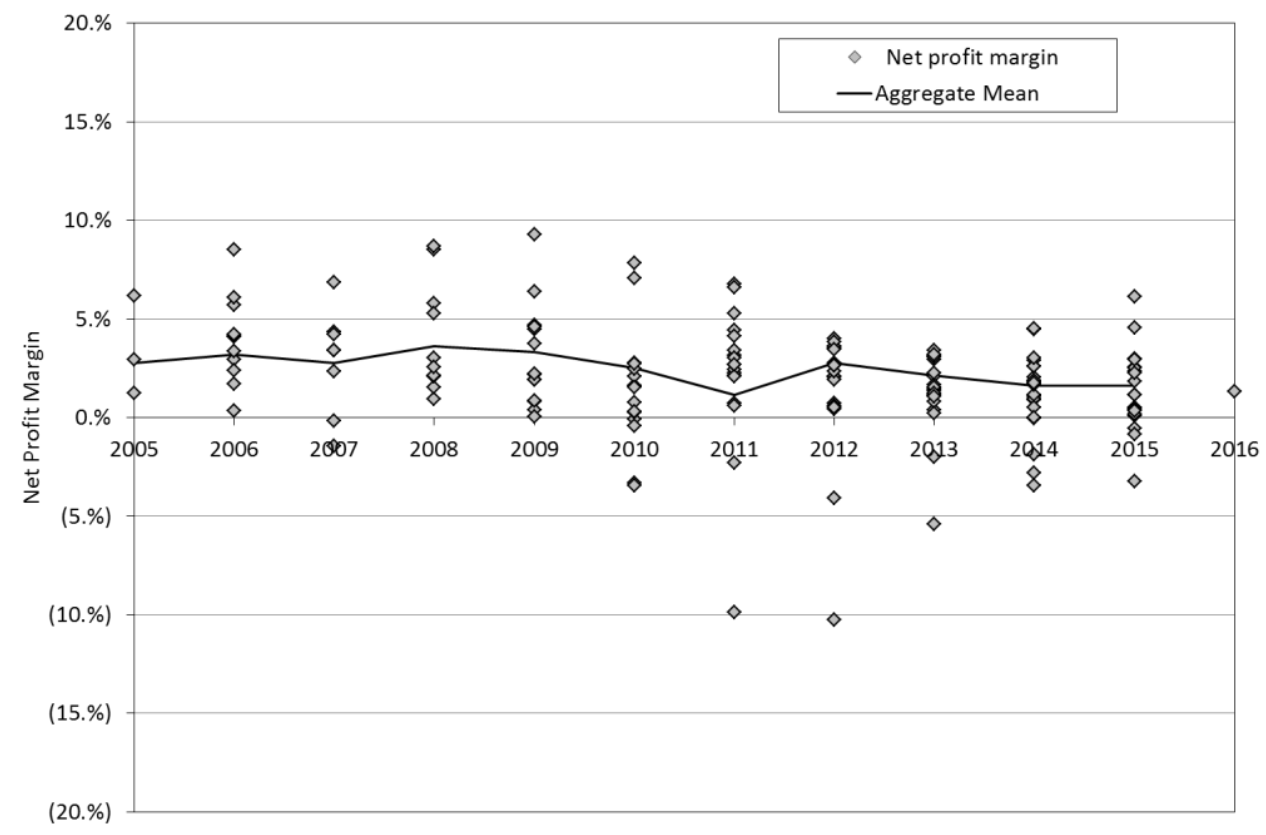

Figure 2: Net profit margin for years 2006 to 2015

The findings confirm that large commercial construction companies in the state of Victoria currently earn a small net profit margin and this margin has declined considerably in recent years. The drastic fall of the aggregated NPM from 3.6\% in 2008 to $1.6 \%$ in 2015 is particularly disconcerting. Using a different data set and a smaller sample of Victorian companies, Deloitte (2016) also reported declining profit margins that averaged $1.7 \%$ in $2010-11$ to only $0.4 \%$ in $2014-15$. From an operational perspective, these construction companies are facing a period of increased competitive forces leading to erosion of profits either to maintain or increase revenues. The convergence to a lower profit margin for larger construction firms (represented by revenues exceeding $\$ 1$ billion) further reinforces the view that average profit margins for the entire sector is declining and that large companies are adopting a strategy of chasing revenues as opposed to chasing profits. Davidsson et al. (2009) have shown, from empirical tests on large longitudinal data sets, that highly profitable companies have decreased risk of poor performance compared to companies adopting a high growth strategy.

The finding that companies with larger revenues reported lower profit margin contradicts the observations from Fadel (1977) and Akintoye and Skitmore (1991). The circumstances where construction companies can no longer achieve economies of scale or achieve a better profit from greater turnover is clearly disconcerting and needs further investigation. Perhaps the inference to be drawn here is that the industry is entering a phase of intense competition or increasing commoditisation, where no single company within the sector is able to sustain an enduring competitive advantage.

An exacerbating factor in loss of profit is likely the rising costs of wages. While wages for the construction sector stands at $12.2 \%$, compared with $19.5 \%$ for all sectors combined, this conceals the fact that some $46 \%$ of revenue payments are made out to subcontractors. The average entry-level salary for a construction labourer, at $\$ 144,506$ (equivalent to $\$ 54 /$ hour), is higher than for any other profession, except for medical practitioners. The growth in wages under EBA agreements is stronger in building construction than in any other industry. Moreover, wages growth in Victorian construction, at $13.4 \%$, continues to outpace growth in other states. 
While the price of construction across Australia has risen at $1.0 \%$ per annum, the price rise in Victoria is $1.5 \%$. At the same time the rise in wage costs has risen by $5.0 \%$. Meanwhile, the productivity of labour in the sector has been falling, year on year, since 2004-5. Again, construction labour productivity in Victoria is lower than in other states.

From an investment perspective, the fall of the ROE from $44 \%$ in 2008 to $21 \%$ in 2015 is similarly disconcerting, but not altogether unexpected given that fall in ROE is proportional to the decline in profits.

The loss of profitability has led to an increase in the use of trade credit in these companies. Ive and Murray (2013) have examined the role of trade credit, defined as the ratio of trade payables to total assets, in order to finance increasing levels of output and turnover in the UK. The trade credit levels from $16 \%$ to $27 \%$ before 2010 is synonymous to the weighted mean of $19.7 \%$ reported for the construction sector in the UK. However, the increase of the trade credit in Victoria in excess of 30\% is significantly higher and indicates that these companies are increasingly transferring project and business risks to their suppliers and sub-contractors.

Although there is no evidence in this study to suggest that the poor profitability and returns on capital employed, concurrently with the higher leverage for these construction companies are directly linked to the higher incidence of insolvencies in the sector, the data from 2010 onward suggest that a number of these companies are taking on losses. The construction industry has consistently been overrepresented in insolvency statistics between $17 \%$ and $20 \%$ during this period (ASIC, 2017). The longer these conditions persist, the likelihood that these construction companies will find themselves in financial distress will certainly increase.

\section{Conclusions}

This study has found evidence of a steady decline in profitability for Victorian commercial construction companies for the period 2006 to 2015. The low profitability may be attributed to increased competitiveness in the market, reducing efficiencies, and higher labour costs in the sector. A corresponding decline in returns on equity and on capital employed over the same period is also confirmed. There is also some evidence of a "grow revenue" business model that has previously been suggested to lead to poorer company performance in the longer term.

The implications are significant, and indicate a shake-up in the industry is inevitable. Reducing profits foretell a reduction in industry players. In 2015, the construction sector experienced the highest number of firms going into liquidation, with $18 \%$ of the country's total. Nevertheless, sector rationalization is also occurring in the form of mergers and acquisitions, where assets are hopefully transferred to those better able to extract efficiencies. A number of Victorian companies have attracted the attention of foreign investors, such as the reported acquisition of $40 \%$ Probuild by Wilson Bayly Holmes Ovcon (WBHO) in 2001 followed by a further 49.9\% in 2012. More recent foreign investment include the acquisition of Icon Co. in 2015 and Cockram Construction in 2017 by Kajima Corporation, and of John Holland by the China Communications Construction Company (CCCC) in 2014 (Chandler, 2016).

The warning to firms unprepared or unable to adapt, is that a "grow revenue" business model over a "grow profits" approach may sustain cash-flow in the shorter-term but not a viable longer term strategy. Politicians and the wider community should also take note. Failure to address rising costs in the construction industry will not just see project costs go up, but may see needed investment cancelled or taxes increased. A projected 13\% increase in labour costs, without accompanying productivity gains, will add $\$ 148$ million to the current Victorian government's infrastructure shopping list (Deloitte, 2016). 


\section{References}

Akintoye, A. \& Skitmore, M. (1991). Profitability of UK construction companies. Construction Management and Economics 9(4), 311-325.

Altman, E.I. (1968). Financial ratios, discriminant analysis and the prediction of corporate bankruptcy. The Journal of Finance 23(4), 589-609.

Australian Securities and Investments Commission (ASIC) (2017). Insolvency statistics, Retrieved from http://asic.gov.au/regulatory-resources/find-a-document/statistics/insolvency-statistics/

Beaver, W.H. (1966). Financial ratios as predictors of failure, Journal of Accounting Research, Empirical Research in Accounting: Selected Studies 1966, Wiley, Hoboken, New Jersey, 4, 71-111.

Chandler, D. (2016). Construction companies - Something to watch in 2016, Sourceable, 15th February, 2016, Retrieved from https://sourceable.net/construction-companies-something-to-watchin-2016

Davidsson, P., Steffens, P. \& Fitzsimmons, J. (2009). Growing profitable or growing from profits: Putting the horse in front of the cart? Journal of business venturing, 24(4), 388-406.

Deloitte (2016). Construction sector outlook, labour costs and productivity. Deloitte Access Economics, Sydney, Australia.

Fadel, H. (1977). The predictive power of financial ratios in the British construction industry, Journal of Business Finance and Accounting 4(3) 339-352.

Horrigan, J.O. (1968) A short history of financial ratio analysis, The Accounting Review 43(2), 284-294.

Ive, G. \& Murray, A. (2013). Trade credit in the UK construction industry: an empirical analysis of construction contractor financial positioning and performance.

Kelly, A. (2016). Industry Report E3021 - Commercial and Industrial Building Construction in Australia, March 2016, IBISWorld. 